JOTE Volume 3 Nomor 1 Tahun 2021 Halaman 71-76

JOURNAL ON TEACHER EDUCATION

Research \& Learning in Faculty of Education

\title{
ANALISIS SOAL UJIAN AKHIR SEMESTER GANJIL MATA PELAJARAN SEJARAH INDONESIA KELAS XI DI SMA NEGERI 3 MUKOMUKO TAHUN PELAJARAN 2020/2021
}

\author{
Titik Kartiningsih ${ }^{1}$, Zulfa ${ }^{2}$, Jaenam ${ }^{3}$ \\ Program Studi Pendidikan Sejarah, STKIP PGRI Sumatera Barat \\ Email : titikkartiningsih23@gmail.com
}

\begin{abstract}
Abstrak
Tujuan penelitian ini adalah untuk menganalisis sebaran materi pokok, Kompetensi Dasar, Indikator Pencapaian Kompetensi, dan tingkat berfikir pada soal Ujian Akhir Semester Ganjil mata pelajaran sejarah Indonesia kelas XI di SMA Negeri 3 Mukomuko. Metode yang digunakan yaitu deskriptif kuantitatif. Teknik pengumpulan data adalah Studi Dokumentasi. Teknik analisis data dengan cara memilah soal kemudian menggolongkan soal, lalu mengklasifikasi dengan persentase. Hasil dari penelitian yaitu bahwa sebaran materi dan Kompetensi Dasar pada soal Ujian Akhir Semester ganjil dikategorikan belum merata, karena terdapat satu Kompetensi Dasar yang tidak ada soalnya. Persebaran Indikator Pencapaian Kompetensi pada soal Ujian Akhir Semester ganjil belum juga merata, karena banyak indikator yang tidak memiliki soal, dan satu indikator yang yang terdapat banyak soal. Untuk sebaran tingkat berfikir pada soal Ujian Akhir Semester ganjil belum merata. Soal lebih banyak menggunakan tingkat berfikir level C1, C2 dan C3, sehingga termasuk soal yang LOTS.
\end{abstract}

Kata Kunci: Analisis Soal Ujian Akhir, Materi, Tingkat Berfikir

\section{Abstract}

The purpose of this study was to analyze the distribution of subject matter, Basic Competencies, Indicator of Competency Achievement, and level of thinking on the Odd Semester Final Exam questions for Indonesian history class XI at SMA Negeri 3 Mukomuko. The method used is descriptive quantitative. The data analysis technique is by sorting the questions, then classifying them by percentage. The results of the research are that the distribution of material and Basic Competencies on the odd Semester Final Examination questiuns is categorized as uneven, because there is one Competence that does not have a problem. The distribution of Competency Achievement Indicators on odd Semester Final Examination questions is also uneven, because many indicators do not have questions, and one indicators contains many questions. For the distribution of thingking levels on the odd Semester Final Exam questions, it is not evenly distributed. More using the level of thingking levels C, C2 and C3, including LOTS questions.

Keywords: Final Exam Question Analysis, Material, Thinking Level 


\section{PENDAHULUAN}

Pendidikan merupakan salah satu kebutuhan manusia, karena dengan adanya pendidikan manusia dapat memperoleh pengetahuan. Pendidikan yang baik dan bermutu akan mengahasilkan manusia yang berkualitas. Pendidikan juga merupakan kegiatan yang bersifat universal, yang terdapat dimanapun dan kapanpun, sehingga memiliki kemampuan dan keterampilan untuk membawa bangsa ini kearah yang lebih baik.

Mutu pendidikan sangat dipengaruhi oleh kegiatan pembelajaran di sekolah. Pembelajaran merupakan dua arah komunikasi, yang mana mengajar dilakukan oleh guru dan belajar dilakukan oleh peserta didik. Untuk meningkatkan mutu pendidikan yang bermaksud agar pembelajaran dilakukan dengan baik, maka pemerintah terus menerus melakukan upaya penyempurnaan kurikulum. Pentingnya pendidikan dalam pembangunan bangsa telah mendorong pemerintah melakukan berbagai usaha untuk meningkatkan mutu pendidikan, yang tinggi rendahnya suatu mutu pendidikan tidak terlepas dari kompenen yang mampu menentukan keberhasilan peserta didiknya. Salah satu komponen dalam penyempurnaan sistem pendidikan yaitu pada peningkatan profesionalisme tenaga kependidikan.

Sejarah adalah mata pelajaran yang bertujuan untuk meyadarkan peserta didik bahwa adanya keberagaman hidup pada masing-masing masyarakat serta cara pandang yang berbeda terhadap masa lampau untuk mememahami masa kini dan membangun pengetahuan dan pemahaman dalam menghadapi masa yang akan datang. Pembelajaran sejarah juga menanamkan pengetahuan dan nilai-nilai mengenai proses perubahan dan perkembangan masyarakat Indonesia dan dunia dari masa lampau hingga sekarang.

Evaluasi merupakan bagian komponen utama dan juga merupakan tahap yang dicapai guru dalam mengetahui keefektifan pembelajaran. Evaluasi atau penilaian dalam pembelajaran sejarah berguna sebagai acuan dalam pencapaian tujuan pembelajaran sejarah yang telah ditetapkan. Evaluasi merupakan proses penilaian dalam pengambilan keputusan dengan menggunakan instrument, baik instrumen tes maupun non tes. Bentuk tes yang biasanya digunakan oleh lembaga formal dalam Ujian Akhir Semester (UAS) merupakan tes dalam bentuk objektif (soal pilihan ganda).

Tes pilihan ganda memiliki karateristik yang baik untuk sebagai alat pengukuran hasil belajar peserta didik. Karakter yang baik tersebut, yaitu lebih fleksibel dalam implementasi evaluasi dan efektif untuk mengukur tercapai atau tidaknya tujuan belajar mengajar. Oleh karena itu kuantitas butir soal dari tes objektif menjadi hal yang dipertimbangkan demi mendapatkan hasil belajar yang diinginkan. Tes merupakan alat ukur yang sering digunakan untuk mengukur keberhasilan peserta didik dalam mencapai kompetensi. Melihat pentingnya suatu tes dalam mengukur kemampuan peserta didik, maka guru seharusnya merancang suatu tes dengan baik dan sesuai dengan indikator pencapaian kompetensi. 
Menurut Djaali dan Muljono (Putri, 2019), penilaian adalah suatu proses membandingkan suatu objek atau gejala dengan mempergunakan patokanpatokan tertentu seperti baik tidak baik, memadai tidak memadai, memenuhi syarat tidak memenuhi syarat, dan sebagainya. Penilaian juga diartikan sebagai kegiatan menafsirkan data hasil pengukuran atau kegiatan untuk memperoleh informasi tentang percapaian kemajuan belajar peserta didik. Proses penilaian mencakup pengumpulan bukti yang menunjukkan pencapaian belajar peserta didik. Oleh karena itu, kegiatan penilaian tidak hanya terbatas pada karakteristik metode mengajar, kurikulum, fasilitas, dan administrasi sekolah.

Instrument penilaian untuk peserta didik dapat berupa metode atau prosedur formal dan informal untuk menghasilkan informasi tentang peserta didik. Instrument penilaian juga dapat berupa tes tertulis, tes lisan, lembar pengamatan, pedoman wawancara, tugas rumah, dan sebagainya. Dengan demikian, maka dapat disimpulkan bahwa penilaian dalam pembelajaran adalah kegiatan membandingkan atau menerapkan hasil pengukuran untuk memberikan nilai terhadap objek penilaian dalam konteks pembelajaran.

Indikator dalam kisi-kisi merupakan pedoman dalam merumuskan soal yang dikehendaki. Selain itu berdasarkan kaidah penulisan soal yaitu soal harus sesuai dengan indikator, setiap pertanyaan harus diberikan batasan jawaban yang diharapkan, materi yang dipertanyakan harus sesuai dengan tujuan pengukuran, materi yang diujikan harus sesuai dengan jenjang jenis sekolah atau tingkat kelas.

Sesuai dengan fenomena dan permasalahan yang penulis amati di SMA Negeri 3 Mukomuko tempat penulis melakukan kegiatan PPLK untuk soal Ujian Akhir Semester ganjil dibuat oleh guru bidang studi sejarah. Sebanyak 40 soal yang terbagi menjadi 20 soal untuk sesi pertama (A) dan 20 soal untuk sesi kedua (B). Ujian Akhir Semester ganjil dilaksanakan dengan sistem shift berdasarkan penomoran ganjil genap pada absensi peserta didik. Dalam pembuatan soal belum dilakukan kegiatan analisis soal, karena biasanya analisis soal dilakukan setelah soal diujikan. Bentuk soal yang diujikan pada Ujian Akhir Semester ganjil yaitu soal objektif atau soal pilihan ganda dengan pilihan jawaban terdiri dari lima opsi jawaban.

Berdasarkan hasil temuan awal pada Soal Ujian Akhir Semester ganjil mata pelajaran sejarah Indonesia kelas XI ditemukan bahwa sebaran soal dengan materi pokok belum merata. Sebaran soal dengan Kompetensi Dasar juga belum merata. Banyaknya Indikator Pencapaian Kompetensi yang belum mempunyai soal. Sebaran soal terhadap tingkat berfikir didominasi pada tingkat berfikir level Mengingat ( $\mathrm{Cl}$ ) dan Memahami (C2). Hal tersebut disebabkan oleh belum dilakukan kegiatan analisis butir soal pada soal Ujian Akhir Semester ganjil. Jadi soal yang diujikan belum dilakukan analisis soal terlebih dahulu.

Mengenai soal objektif sebagai salah satu instrument penguji, maka ditemukan masalah yaitu soal soal yang belum teruji kuantitas butir soalnya. Padahal ada banyak cara untuk mengetahui kualitas dan kuantitas butir soal, diantaranya dapat dilakukan dengan cara manual atau menggunakan bantuan komputer. Seharusnya dilakukan analisis butir soal yang berkaitan dengan pengkajian tiap butir soal agar didapatkan gambaran tentang bagaimana kualitas 
tes yang telah dibuat sehingga sesuai dengan tujuan pembelajaran yang telah disusun.

Evaluasi sangat dibutuhkan dalam berbagai kegiatan, salah satunya adalah kegiatan pembelajaran. Evaluasi dalam (Nuriyah, 2014) merupakan usaha untuk memperoleh informasi tentang perolehan belajar peserta didik secara menyeluruh, baik dalam bidang oengetahuan, konsep, sikap, nilai, maupun keterampilan proses. Hal ini dapat digunakan oleh guru sebagai balikan ataupun keputusan yang sangat diperlukan dalam menentukan strategi belajar mengajar. Dengan maksud guru harus mengadakan peniaian, baik terhadap proses maupun terhadap hasil dari kegiatan belajar mengajar peserta didik.

Evaluasi pembelajaran adalah proses untuk menetukan nilai belajar dan pembelajaran yang dilaksanakan, dengan melalui kegiatan penilaian atau pengukuran belajar dan pembelajaran. Dengan adanya evaluasi, peserta didik dapat mengetahui sejauh mana keberhasilan yang telah dicapai selama mengikuti pendidikan. Pada kondisi ini dimana peserta didik mendapatkan nilai yang memuaskan, maka akan memberikan dampak berupa suatu stimulus, motivator agar peserta didik dapat lebih meningkatkan prestasi. Jika hasil yang dicapai tidak memuaskan, maka peserta didik akan berusaha untuk memperbaiki kegiatan belajar, walaupun demikian sangat diperlukan pemberian stimulus yang positif dari guru atau tenaga pendidik agar peserta didik tidak putus asa.

Pada hakekatnya tujuan evaluasi adalah untuk memperoleh informasi yang akurat dan objektif tentang suatu program. Informasi tersebut dapat berupa proses pelaksanaan program, dampak/hasil yang dicapai, efisiensi serta pemanfaatan hasil evaluasi yang difokuskan untuk program itu sendiri, yaitu untuk mengambil keputusan apakah dilanjutkan, diperbaiki atau dihentikan. Selain itu, juga dipergunakan untuk kepentingan penyusunan program berikutnya maupun penyusunan kebijakan yang terkait dengan program pendidikan (Anidi, 2017).

Berdasarkan teori Evaluasi, disini penulis ingin melihat bagaimana gamabaran tentang Analisis Soal Ujian Akhir Semester Ganjil Mata Pelajaran Sejarah Indonesia Kelas XI Di SMA Negeri 3 Mukomuko Tahun Pelajaran 2020/2021.

\section{METODE}

Metode penelitian yang digunakan dalam penelitian ini adalah metode deskriptif kuantitatif. Dalam (Sugiyono, 2013) metode deskriptif adalah penelitian yang berusaha menggambarkan dan menginterpretasikan objek sesuai dengan apa adanya pada saat penelitian dilakukan, sedangkan metode kuantitatif adalah data yang berupa angka-angka. Waktu pelaksanaan penelitian ini rencananya dilaksanakan pada semester genap tahun ajaran 2020/2021. Penelitian ini dilaksanakan di SMA Negeri 3 Mukomuko. Dalam upaya mendapatkan keterangan dan data soal yang dibuat oleh guru yang relevan dengan permasalahan yang diteliti, maka informan dalam penelitian ini adalah kepala sekolah dan guru sejarah yang mengajar di SMA Negeri 3 Mukomuko. Dalam penelitian ini, peneliti menggunakan teknik penggumpulan data dengan observasi dan dokumentasi. 
Teknik analisis data dilakukan setelah mendapatkan soal yang akan diteliti dengan soal tersebut dilakukan analisis butir soal yang dilihat dari sebaran materi, Kompetensi Dasar, Indikator Pencapaian Kompetensi serta tingkat berfikir yang terdapat dalam soal tersebut. Analisis dilakukan dengan cara memilah soal kemudian menggolongkan soal sesuai dengan sebaran materi, Kompetensi Dasar, Indikator Pencapaian Kompetensi yang tertera pada RPP serta analisis tingkat berfikir menggunakan taksonomi Bloom revisi. Setelah itu dikelompokan dalam bentuk tabel, kemudian diuraikan dengan menggunakan persentase (\%) dalam bentuk deskripsi yaitu mengemukakan seberapa \% soal yang mencakup sesuai dengan sebaran materi, kompetensi dasar, indikator pencapaian kompetensi dan tingkat berfikir yang ditemukan dalam soal.

\section{HASIL PEMBAHASAN}

Berdasarkan penelitian tentang analisis soal ujian akhir semester ganjil mata pelajaran sejarah Indonesia kelas XI di SMA Negeri 3 Mukomuko tahun pelajaran 2020/2021, dilihat dari teori evaluasi pada hakekatnya evaluasi adalah untuk memperoleh informasi yang akurat dan objektif tentang suatu program. Informasi tersebut dapat berupa proses pelaksanaan program, dampak/hasil yang dicapai, efisiensi serta pemanfaatan hasil evaluasi yang difokuskan untuk program itu sendiri, yaitu untuk mengambil keputusan apakah dilanjutkan, diperbaiki atau dihentikan. Evaluasi pembelajaran adalah proses untuk menetukan nilai belajar dan pembelajaran yang dilaksanakan, dengan melalui kegiatan penilaian atau pengukuran belajar dan pembelajaran yang dapat dilakukan melalui kegiatan ujian akhir semester.

Ulangan Akhir Semester ganjil tahun pelajaran 2020/2021 dilaksanakan pada bulan Desember yang dibagi menjadi dua sesi yaitu sesi pertama dan sesi kedua. Pelaksanaan ujian akhir semester ganjil bertujuan untuk mengetahui sejauh mana pemahaman dan penguasaan materi oleh peserta didik terhadap kompetensi dasar yang telah dipelajari oleh peserta didik pada mata pelajaran sejarah Indonesia baik secara daring maupun luring dalam satu semester.

Hasil penelitian menunjukkan bahwa analisis soal Ujian Akhir Semester ganjil yang diujikan di SMA Negeri 3 Mukomuko masih belum merata. Pada sebaran materi pokok dan Kompetensi Dasar hanya satu atau dua saja Kompetensi Dasar yang mendominasi pada soal. Untuk sebaran Indikator Pencapaian Kompetensi masih banyak indikator yang belum mempunyai soal. Pada sebaran tingkat berfikir soal didominasi oleh tingkat berfikir mengingat (C1) dan memahami (C2). Kesimpulan dari hasil penelitian yaitu bahwa sebaran materi dan Kompetensi Dasar pada soal Ujian Akhir Semester ganjil mata pelajaran sejarah Indonesia tahun pelajaran 2020/2021 dikategorikan belum merata, karena terdapat satu Kompetensi Dasar yang tidak ada soalnya. Persebaran Indikator Pencapaian Kompetensi pada soal Ujian Akhir Semester ganjil mata pelajaran sejarah Indonesia kelas XI tahun pelajaran 2020/2021 belum juga merata, karena banyak indikator yang tidak memiliki soal, dan satu indikator yang yang terdapat banyak soal. Untuk sebaran tingkat berfikir pada soal Ujian Akhir Semester ganjil mata pelajaran sejarah Indonesia kelas XI tahun pelajaran 2020/2021 belum merata. Soal lebih banyak menggunakan tingkat berfikir level C1, C2 dan C3, sehingga termasuk soal yang LOTS. 


\section{KESIMPULAN}

Berdasarkan hasil penelitian dapat disimpulkan bahwa sebaran materi dan Kompetensi Dasar pada soal Ujian Akhir Semester ganjil mata pelajaran sejarah Indonesia tahun pelajaran 2020/2021 dikategorikan belum merata, karena terdapat satu Kompetensi Dasar yang tidak ada soalnya. Persebaran Indikator Pencapaian Kompetensi pada soal Ujian Akhir Semester ganjil mata pelajaran sejarah Indonesia kelas XI tahun pelajaran 2020/2021 belum juga merata, karena terdapat banyak indikator yang tidak memiliki soal, dan satu indikator yang yang terdapat banyak soal. Untuk sebaran tingkat berfikir pada soal Ujian Akhir Semester ganjil mata pelajaran sejarah Indonesia kelas XI tahun pelajaran 2020/2021 belum merata. Soal lebih banyak menggunakan tingkat berfikir level C1, C2 dan C3. Sedangkan untuk level C4, C5 dan C6 tidak terdapat soal. Sehingga soal yang diujikan termasuk dalam soal LOTS, karena soal yang diujikan didominasi oleh tingkat berfikir C1,C2, dan C3.

\section{DAFTAR PUSTAKA}

Abduh, M. (2019). Paduan Penilaian Tes Tertulis (D. Hadiana (ed.)). Pusat Penilaian Pendidikan.

Aman. (2011). Model Evaluasi Pembelajaran Sejarah. Ombak.

Anidi. (2017). Evaluasi Program Pembelajaran. Parama Publishing.

DJ, L. (2011). Evaluasi Pendidikan. UNP Press Padang.

Kusuma, M. (2016). Evaluasi Pendidikan Pengantar, Kompetensi dan Implementasi. Parama IImu.

Kuswana, W. S. (2012). Taksonomi Kognitif Perkembangan Ragam Berfikir (A. Kamsyach (ed.); cetakan pe). PT Remaja Rosdakarya.

Putri, R. I. I. (2019). Evaluasi Pembelajaran (Revisi 1). Universitas Sriwijaya.

Ratnawulan, E., \& Rusdiana. (2014). Evaluasi Pembelajaran dengan pendekatan kurikulum 2013. Pustaka Setia.

Ratnawulan, E., \& Rusdiana. (2015). Evaluasi Pembelajaran. CV Pustaka Setia.

Sugiyono. (2011). Metode Penelitian Pendidikan (Pendekatan Kuantitatif, Kualitatif dan $R \& D)$. Alfabeta.

Sugiyono. (2013). Metode Penelitian Kuantitatif Kualitatif dan R\&D (Cetakan ke). Alfabeta,cv. 